\title{
STRATEGI PENGEMBANGAN COMMUNITY BASED TOURISM SEBAGAI UPAYA PEMBERDAYAAN EKONOMI MASYARAKAT DI KULON PROGO
}

\author{
Sugi Rahayu ${ }^{1}$, Utami Dewi ${ }^{2}$, dan Kurnia Nur Fitriana ${ }^{3}$
}

\begin{abstract}
This article aims to describe the development of CBT in Kulon Progo and obstacles faced. The method used descriptive qualitative design with Research and Development ( $R$ and D) from Borg and Gall (1998). The technique of collecting data used interviews, observation, documentation and Focus Group Discussion (FGD). Data were analyzed using interactive analysis Miles and Huberman. The study found that some strategies may be taken in the development of CBT: to see, to do, to buy, to share, to empower and to sustain of all agriculture, economics and social-cultural potentials in Kulon Progo. Moreover, in implementing CBT, there are steps should be considered as follows: understanding all potentials and resources, establishing CBT's management, and integrating roles of all stakeholders. However, there are several hindrances in the implementation model that needs to be taken by the manager of CBT in Kulon Progo are: 1). Un-sufficient budget; 2) the lack of human resources; 3) un-readiness of community in viewing the importance of tourism management; 4) the lack of support from private sectors; 5) lack of infrastructure.
\end{abstract}

Keywords: CBT, Strategy, and Empowerment

\begin{abstract}
ABSTRAK
Artikel ini bertujuan untuk mengetahui bagaimana pengembangan CBT di Kabupaten Kulon Progo dan hambatan yang dihadapi. Penelitian ini menggunakan metode deskriptif kualitatif dengan desain Research and Development ( $R$ and $D)$ dari Borg dan Gall (1998). Teknik pengumpulan data menggunakan wawancara, observasi, dokumentasi dan Focus Group Discussion (FGD). Teknik analisis data menggunakan analisis interaktif Miles dan Huberman. Hasil penelitian menemukan pengembangan CBT meliputi to see, to do, to buy, to share, to empower dan to sustain terhadap potensi alam, sosial budaya, kerajinan dan potensi lain yang dimiliki oleh Kabupaten Kulon Progo. Selain itu, pengelola dan seluruh stakeholder perlu mengikuti tahapan dalam implementasi CBT meliputi: identifikasi potensi, pembentukan pengelola CBT, kepemimpinan dan integrasi peran seluruh stakeholders. Beberapa hambatan yang dihadapi yaitu kurangnya: (1) sumber dana, (2) sumber daya manusia, (3) kesiapan masyarakat; (4) dukungan dari pihak swasta atau pengusaha wisata dan investor; dan (5) infrastruktur.
\end{abstract}

Kata kunci: CBT, Strategi dan Pemberdayaan

\footnotetext{
1, 2, 3 Dosen, Jurusan Ilmu Administrasi Negara, Universitas Negeri Yogyakarta. email: sugirahayu@uny.ac.id, utami.dewi@uny.ac.id,dan kurnianurfitriana@uny.ac.id
} 


\section{PENDAHULUAN}

Pariwisata merupakan sektor unggulan yang dapat dijadikan tumpuan untuk meningkatkan kesejahteraan masyarakat. Sektor pariwisata mampu menghidupkan ekonomi masyarakat di sekitarnya, pariwisata juga diposisikan sebagai sarana penting dalam rangka memperkenalkan budaya dan keindahan alam daerah terkait. Kulon Progo merupakan salah satu kabupaten di Daerah Istimewa Yogyakarta (DIY) yang memiliki modal dasar berupa alam yang indah meliputi pantai, waduk, goa, dan Perbukitan Menoreh yang mempesona untuk dinikmati oleh wisatawan maupun menantang untuk dijelajahi para petualang. Destinasi wisata yang dimiliki Kulon Progo yaitu: wisata alam, wisata buatan, wisata sejarah, wisata religi, wisata edukasi, wisata minat khusus, wisata kerajinan, wisata kuliner, dan wisata budaya. Jenis wisata tersebut dapat dikelompokkan sebagai mass tourisms atau sering disebut sebagai wisata konvensioal. Selain memiliki mass tourisms yang beraneka ragam, Kabupaten Kulon progo juga potensial untuk dikembangkan menjadi pariwisata berbasis masyarakat (Community Based Tourism = CBT) yaitu berupa dibangunnya desa wisata.
Pariwisata berbasis masyarakat atau community based tourism berkaitan erat dengan adanya kepastian partisipasi aktif dari masyarakat setempat dalam pembangunan kepariwisataan yang ada. Partisipasi masyarakat dalam pariwisata terdiri dari atas dua perspektif, yaitu partisipasi masyarakat dalam proses pengambilan keputusan dan partisipasi yang berkaitan dengan distribusi keuntungan yang diterima oleh masyarakat dari pembangunan pariwisata. Oleh karena itu pada dasarnya terdapat tiga prinsip pokok dalam strategi perencanaan pembangunan kepariwisatan yang berbasis pada masyarakat atau community based tourism, yaitu :

1. Mengikutsertakan anggota masyarakat dalam pengambilan keputusan.

2. Adanya kepastian masyarakat lokal menerima manfaat dari kegiatan kepariwisataan.

3. Pendidikan Kepariwisataan bagi masyarakat lokal (Sunaryo, 2013: 140).

Suansri (2003) menyebutkan beberapa prinsip dari Comunity-Based Tourism yang harus dilakukan, yaitu: 1) mengenali, mendukung, dan mempromosikan kepemilikan masyarakat dalam pariwisata; 2) melibatkan anggota 
masyarakat dari setiap tahap pengembangan pariwisata dalam berbagai aspeknya, 3) mempromosikan kebanggaan terhadap komunitas bersangkutan; 4) meningkatkan kualitas kehidupan; 5) menjamin keberlanjutan lingkungan; 6) melindungi ciri khas (keunikan) dan budaya masyarakat lokal; 7) mengembangkan pembelajaran lintas budaya; 8) menghormati perbedaan budaya dan martabat manusia; 9) mendistribusikan keuntungan dan manfaat yang diperoleh secara proporsioanal kepada anggota masyarakat; 10) memberikan kontribusi dengan persentase tertentu dari pendapatan yang diperoleh untuk pengembangan masyarakat; dan 11) menonjolkan keaslian hubungan masyarakat dengan lingkungannya.

Pengembangan pariwisata berbasis masyarakat merupakan upaya untuk memberdayakan masyarakat lokal dalam pengembangan pariwisata agar manfaat adanya sektor pariwisata dapat dirasakan langsung oleh masyarakat. Selain memberdayakan masyarakat lokal, pariwisata berbasis masyarakat juga dapat meningkatkan partisipasi aktif dari pihak swasta di bidang jasa pariwisata, seperti pengusaha hotel/penginapan, restoran/warung makan, maupun agen perjalanan. Dengan demikian pengembangan pariwisata dapat menimbulkan efek bola salju (Multiplier effects) terhadap sektor yang lain, seperti sektor ekonomi, sosial, lingkungan, pendidikan dan budaya.

Dalam pengembangan pariwisata berbasis masyarakat, masyarakat sebagai pelaku langsung di lapangan menjadi sorotan utama untuk keberlanjutan pariwisata. Hasil yang diharapkan adalah terciptanya pariwisata berkelanjutan yang banyak memberikan keuntungan baik bagi pemerintah, masyarakat, maupun pihak swasta. Dalam hal ini peran pemerintah daerah sangat dibutuhkan untuk meningkatkan partisipasi masyarakat melalui sosialisasi sadar wisata agar manfaat dari pariwisata dapat dirasakan langsung oleh masyarakat daerahnya. Hal ini menjadi penting karena Kabupaten Kulon Progo sebagai daerah agraris, mayoritas penduduknya masih berusaha pada sektor pertanian dengan mata pencaharian utama sebagai petani.

Upaya agar masyarakat Kulon Progo sadar wisata maka harus dibangun mindset sadar wisata mengingat potensi pariwisata di daerah ini kurang berkembang secara optimal. Rasa ikut memiliki (handarbeni) perlu ditumbuhkan dengan menanamkan pemahaman tentang arti penting pariwisata sebagai salah satu sektor untuk mendorong tumbuh dan kuatnya ekonomi, sehingga mempercepat 
kesejahteraan masyarakat. Untuk itu kemitraan pemerintah, pelaku usaha, dan masyarakat perlu dikembangkan dalam mempercepat kesejahteraan masyarakat melalui pariwisata. Masyarakat ikut berperan serta dalam pembangunan pariwisata termasuk dalam pemasarannya.

Artikel ini akan mengulas lebih dalam tentang pengembangan community based tourism (CBT) sebagai salah satu wujud partisipasi masyarakat dalam memajukan sektor pariwisata guna peningkatan kesejahteraan masyarakat. Dalam pengembangan CBT di Kabupaten Kulon Progo diperlukan beberapa tahapan yang perlu diambil agar CBT dapat berjalan untuk pemberdayaan dan peningkatan kesejahteraan masyarakat. Selain itu, pada penerapan CBT terdapat hambatan-hambatan yang dihadapi oleh masyarakat, baik hambatan internal maupun eksternal. Selain itu artikel ini akan menganalisis solusi untuk mengatasi hambatan tersebut.

\section{METODE}

Artikel ini dihasilkan melalui penelitian deskriptif kualitatif, dimana peneliti bertujuan untuk mendeskripsikan dan menganalisis implementasi model pengembangan pariwisata berbasis masyarakat (Community Based Tourism) serta mengetahui hambatan dalam implementasi model CBT sebagai keberlanjutan strategi pemberdayaan ekonomi masyarakat.

Lokasi penelitian adalah di Kabupaten Kulon Progo yang memiliki sejumlah potensi wisata unggulan dan desa wisata yang mulai berkembang. Informan dalam penelitian ini adalah Kepala dan pejabat Dinas Kebudayaan Pariwisata Pemuda dan Olahraga, Dewan Perwakilan Rakyat Daerah, Dinas Pendapatan Pengelolaan Keuangan dan Asset; Bappeda Bidang Ekonomi; Dinas Perindustrian, Perdagangan, dan Energi Sumber Daya Mineral Kabupaten Kulon Progo, Kelompok- kelompok sadar wisata (Pokdarwis), pengelola desa wisata di Kabupaten Kulon Progo dan para pakar dalam bidang kepariwisataan seperti Pusat Pariwisata UGM dan Yayasan Stupa Indonesia.

Teknik pengumpulan data menggunakan wawancara, observasi, dokumentasi dan Focus Group Discussion (FGD). Dalam menyelesaikan penelitian ini, peneliti menggunakan prosedur penelitian dan pengembangan (Research and Development) yang dikembangkan oleh Borg and Gall (1998). Teknik analisis data menggunakan analisis interaktif Miles dan Huberman yang terdiri dari pengumpulan data, penyajian 
data, reduksi data dan penarikan kesimpulan.

\section{HASIL DAN PEMBAHASAN}

\section{Kesiapan Masyarakat}

dalam

\section{Penerapan CBT}

Pengembangan pariwisata berbasis masyarakat (Community Based Tourism/CBT) merupakan upaya untuk memberdayakan masyarakat lokal dalam pengembangan pariwisata agar manfaat adanya sektor pariwisata dapat dirasakan langsung oleh masyarakat. Masyarakat sebagai pelaku langsung di lapangan menjadi sorotan utama untuk keberlanjutan pariwisata. Hasil yang diharapkan adalah terciptanya pariwisata berkelanjutan yang banyak memberikan keuntungan baik bagi pemerintah, masyarakat, maupun pihak swasta.

Untuk

mewujudkan pengembangan pariwisata berjalan dengan baik dan dikelola dengan baik maka hal yang paling mendasar dilakukan adalah bagaimana memfasilitasi keterlibatan yang luas dari komunitas lokal dalam proses pengembangan dan memaksimalkan nilai manfaat sosial dan ekonomi dari kegiatan pariwisata untuk masyarakat setempat. Masyarakat lokal memiliki kedudukan yang sama pentingnya sebagai salah satu pemangku kepentingan (stakeholder) dalam pembangunan kepariwisataan, selain pihak pemerintah dan industri swasta yang harus dipersiapkan menghadapi pengembangan pariwisata di wilayahnya.

$\begin{array}{rcr}\text { Potensi } & \text { pariwisata } & \text { yang } \\ \text { dikembangkan } & \text { sebagai } & \text { model }\end{array}$
pengembangan CBT di Kabupaten Kulonprogo dapat dikelompokkan dalam: (1) Wisata sosial-budaya; untuk pengembangan wilayah Kulonprogo Tengah dan Selatan; (2) Wisata pertanian; untuk pengembangan wilayah Kulonprogo Utara dan Tengah; dan (3) Wisata alam dan lingkungan; untuk pengembangan wilayah Kulonprogo Utara khususnya di perbukitan Menoreh dan pantai selatan. Jenis pariwisata tersebut akan melibatkan partisipasi masyarakat baik sebagai pelaku langsung maupun sebagai pendukung pariwisata. Kegiatan pariwisata di atas juga dapat membangun jiwa kewirausahaan dan kreativitas masyarakat sehingga akan terjadi multiplier effects yang dapat menyejahterakan masyarakat apabila dikelola dengan baik.

Berbagai potensi yang dapat dinikmati (TO SEE), dilakukan (TO DO), dan dibeli ( $\boldsymbol{T} \boldsymbol{O} \boldsymbol{B} \boldsymbol{U} Y$ ) oleh wisatawan dapat ditawarkan dalam penerapan CBT. Potensi yang dapat dinikmati adalah agrowisata, ekowisata dan wisata sosial budaya. Agrowisata merupakan usaha jasa pariwisata sekaligus media promosi, 
ajang pendidikan, diversifikasi produk agribisnis dan pasar berbagai produk lokal sehingga bisa menumbuhkan peluang kerja dan peluang usaha bagi masyarakat lokal. Masyarakat merupakan pelaku langsung kegiatan agrowisata yang memiliki pengalaman turun temurun dalam hal pengelolaan sumber daya alam dan budaya sehingga memiliki komitmen yang kuat untuk mengelola sumber daya alam secara berkelanjutan karena menyangkut kepentingan hidup mereka. Masyarakat merupakan bagian yang tidak terpisahkan dari atraksi agrowisata sehingga pengembangan agrowisata tidak bisa dilakukan tanpa melibatkan masyarakat. Masyarakat yang paling mengetahui potensi agrowisata di wiayahnya yang dapat dikembangkan untuk mendukung pariwisata ini. Beberapa contoh potensi agrowisata yang dapat dikenali di Kabupaten Kulon Progo antara lain:

1. Kulon Progo memiliki berbagai jenis perkebunan yang dapat menjadi daya tarik wisatawan, seperti: (1) kebun teh, cengkih, dan kopi di Nglinggo; (2) cacao (cokelat) dan aneka pengolahanya, Gula jawa/merah, Durian, Buah Naga, Slondok dan Gula Kristal yang merupakan produk unggulan di Kecamatan Kalibawang, (3) kebun bunga krisan di Gerbosari,
Samigaluh, (4) melon, semangka, dan kelapa yang berkembang di beberapa kecamatan.

2. Pertanian dapat dijual menjadi atraksi wisata yang berkaitan dengan mata pencaharian penduduk. Kegiatan bercocok tanam misalnya, wisatawan dilibatkan untuk langsung melakukan kegiatan penanaman padi, mulai dari pembajakan sawah, sampai menanam dan juga memetik/memanen palawija, seperti sayur mayur.

3. Perikanan lele, gurameh, dan jenis ikan yang lain di berbagai desa di Kecamatan Kalibawang. Selain dijual untuk dikonsumsi juga dijual untuk pemancingan.

4. Peternakan Kambing Peranakan Etawa (PE) adalah peternakan unggulan di Sepanjang pegunungan Menoreh terutama dikembangkan di Desa Girimulyo, Pagerharjo, dan Ngargosari, Kulon Progo yang dapat dimanfaatkan susunya.

Selain potensi agrowisata, ekowisata juga merupakan potensi unggulan di Kulon Progo. Ekowisata didefinisikan sebagai kegiatan perjalanan wisata yang dikemas secara profesional, terlatih, dan memuat unsur pendidikan, sebagai suatu sektor/usaha ekonomi, yang mempertimbangkan warisan budaya, 
partisipasi dan kesejahteraan penduduk lokal serta upaya-upaya konservasi sumberdaya alam dan lingkungan (Wood, 2002). Ekowisata merupakan kegiatan yang dianggap sebagai perwujudan pariwisata berkelanjutan, yang memiliki karakteristik spesifik karena adanya kepedulian pada kelestarian lingkungan dan pemberian manfaat ekonomi bagi masyarakat sekitar. Oleh karena itu setiap kegiatan ekowisata harus dapat mengikuti prinsip-prinsip pola pengelolaan berkelanjutan (Fandelli, 2001), yaitu: a) Berbasis wisata alam, b) Menekankan kepada kegiatan konservasi, c) Mengacu kepada kegiatan pariwisata yang berkelanjutan, d) Berkaitan dengan kegiatan pengembangan pendidikan, e) Mengakomodasi budaya lokal, dan f) Memberi manfaat kepada ekonomi lokal.

$$
\text { Beberapa contoh potensi }
$$
ekowisata di Kabupaten Kulon Progo yang dapat dinikmati (TO SEE), dilakukan (TO DO), dan dibeli (TO BUY) oleh wisatawan yang perlu dikenali masyarakat agar dapat dikembangkan menjadi CBT, antara lain: Bendungan Ancol Kalibawang yang terjaga keaslian dan kebersihannya; panorama alam Tritis, Samigaluh yang ditempuh dengan off road menggunakan jeep ; area Kemping di dekat Curug Setawing; dan Arung Jeram di Sungai Progo. Wisata Sosial Budaya. Kulon Progo memiliki potensi wisata seni budaya yang khas dapat dinikmati (TO $S E E$ ), dilakukan (TO DO), dan dibeli (TO $B U Y$ ) oleh wisatawan. Beberapa potensi wisata sosial budaya di antaranya adalah kesenian krumpyung, jathilan, oglek, angguk, incling, dan tari lengger tapeng.

Selain itu, Kulon Progo memiliki potensi wisata religi dan wisata sejarah, antara lain: 1) Goa Maria Sendang Sono, Kalibawang; 2) Gereja Santa Maria Lourdes Promasan, Banjaroyo, Kalibawang; 3) Goa Maria Lawangsih, Purwosari, Girimulyo; 4) Vihara Giriloka, Jatimulyo, Girimuly0; 5) Masjid Sulthoni peninggalan Sunan Kalijaga, Kalibawang; 6) Makam Simbah Kyai Krapyak Tsani, Kalibawang, 7) Gunung Lanang, sebuah bukit kecil di kawasan dusun Bayeman, Sindutan, Temon, Kulonprogo. Pada puncaknya, didapati sebuah bangunan mirip monumen yang diberi nama Sasana Sukma. Puncak ini merupakan tempat dilakukannya berbagai ritual; 8) Wisata sejarah Makam Pahlawan Nasional Nyi Ageng Serang; dan 9) Makam Girigondo (Makam Keluarga Pakualaman).

Kulon Progo juga memiliki potensi industri kerajinan tangan yang menarik, yaitu Batik dan kerajinan serat alam. Kulon Progo memiliki motif batik khas yang disebut Geblek Renteng. Batik motif Geblek Renteng sebagai sebuah simbol merupakan konsep yang disepakati 
bersama. Berisikan ide tentang ciri khas Kulonprogo dan mewakili gagasan bahwa Kulonprogo merupakan sebuah kabupaten yang rakyatnya bersatu membentuk jalinan utuh nan padu. Motif batik tersebut diciptakan seorang pelajar bernama Ales Candra Wibawa pada tahun 2012. Sentra batik Kulon Progo yang sangat dikenal kualitasnya bagus adalah batik tulis Sembungan, Lendah, Kulon Progo yang motifnya sangat khas. Selain kerajinan tangan, Kulon Progo juga memiliki makanan khas yang unik seperti geblek, tempe benguk, growol, gula aren, cenil dan wingko.

Dengan mengenali potensi yang dimiliki Kulon Progo oleh masyarakat, maka tidaklah berlebihan jika pariwisata berbasis masyarakat (CBT) dijadikan sebagai salah satu bentuk model baru pembangunan pariwisata yang mengusung prinsip-prinsip pembangunan berkelanjutan (Sustainable Development) demi pencapaian pendistribusian kesejahteraan rakyat secara lebih merata. Sehingga proses ke depannya pembangunan dan pengembangan sektor kepariwisataan di Kabupaten Kulon Progo dapat tumbuh dan berkembang secara lebih bertanggung jawab.

Selain pengenalan potensi, hal lain yang diperlukan adalah pembentukan pengelola CBT. Di Kulon Progo terdapat 11 desa wisata yang telah dikembangkan, yaitu: (1) Desa Wisata Pendoworejo, (2) Desa Wisata Sermo, (3) Desa Wisata Purwoharjo, (4) Desa Wisata Jatimulyo, (5) Desa Wisata Banjaroya, (6) Desa Wisata Nglinggo, (7) Desa Wisata Kalibiru, (8) Desa Wisata Sidorejo, (9) Desa Wisata Banjarasri, (10) Desa Wisata Glagah, dan (11) Desa Wisata Sidoharjo. $\mathrm{Ke} 11$ desa wisata tersebut belum semuanya berkembang sesuai dengan konsep CBT, sehingga dipandang perlu untuk menyusun model pengembangan CBT untuk diimplementasikan di Kabupaten Kulon Progo.

Berkaitan dengan pengembangan CBT, peneliti menawarkan model implementasi CBT yang melibatkan seluruh stakeholders meliputi pemerintah, swasta, perguruan tinggi, lembaga swadaya masyarakat serta masyarakat itu sendiri. Implementasi model pengembangan CBT bertujuan agar masyarakat terlibat dan berperan serta dalam pengembangan pariwisata, karena masyarakatlah yang mengetahui ciri khas dan potensi di wilayahnya untuk dapat dikembangkan menjadi destinasi wisata sekaligus sebagai proses pembelajaran bagi mereka dalam melestarikan konservasi cagar budaya yang ada di wilayah mereka masing-masing. 
Integrasi Peran dan Strategi CBT

CBT akan dapat berjalan dengan optimal ketika seluruh stakeholders terlibat dalam perencanaan, implementasi dan pengawasannya. Dalam pengembangan CBT, integrasi peran dari seluruh komponen yaitu pemerintah, swasta, lembaga swadaya masyarakat (NGO), perguruan tinggi, dan masyarakat sangat diperlukan. Pemerintah dapat berfungsi sebagai fasilitator dan regulator. Sebagai regulator, pemerintah melalui dinas terkait yaitu Dinas Kebudayaan, Pariwisata dan Olah Raga, Dinas Pendapatan Daerah, Dinas Perindustrian dan Perdagangan dan dinas-dinas terkait lainnya mempunyai fungsi dalam mengatur dan mengawasi pelaksanaan CBT dengan menciptakan regulasi yang mendukung CBT. Selain itu, pemerintah juga sangat berperan dalam mendukung tumbuh kembang CBT melalui penyediaan dana pendampingan (misalnya dana modal atau stimulan rutin) dan kegiatan-kegiatan pengembangan kapasitas pengelola CBT, misalnya pelatihan kewirausahaan, pengelolaan homestay, table manner, public speaking, dan lain-lain.

Pemerintah Kabupaten Kulon Progo mempunyai komitmen yang kuat untuk memajukan sektor pariwisata di Kulon Progo. Berbagai kebijakan dan program telah disusun dalam mengembangkan pariwisata di Kulon Progo, diantaranya adalah:

1. Menyusun perencanaan pengembangan pariwisata di Kabupaten Kulon Progo dalam RIPPARDA

(Rencana

Pengembangan Pariwisata

Daerah). Dalam RIPPARDA berisi master plan pengembangan wisata di Kulon Progo.

2. Mensosialisasikan programprogram pemerintah pusat khususnya yang berkaitan dengan pariwisata.

3. Memfasilitasi (sebagai fasilitator) pengembangan pariwisata melalui pembangunan sarana prasarana pendukung seperti jalan, saluran irigasi, taman dan fasilitas pendukung. Pemberian fasilitas dari pemerintah tidak hanya berupa fisik tetapi juga berupa penambahan wawasan melalui kegiatan peningkatan kapasitas masyarakat seperti pelatihan/training, workshop dan seminar.

4. Memotivasi masyarakat untuk turut serta dalam pengembangan wisata. Motivasi sangat diperlukan agar masyarakat mengetahui kemana arah pembangunan dan pengembangan wisata di Kulon Progo. 
5. Memasarkan atau mempromosikan potensi wisata di Kulon Progo. Kegiatan promosi wisata dilakukan melalui media cetak, website, pameran pariwisata nasional, kunjungan staf promosi ke sekolah-sekolah, dan media sosial seperti facebook, istagram dan lain-lain.

6. Menjalin kerja sama dengan swasta, lembaga swadaya masyarakat dan aktor lain yang memiliki fokus perhatian pada pengembangan wisata. Hal ini terlihat dari kesepakatan antara Dinas Pariwisata Pemerintah Daerah Istimewa Yogyakarta (DIY) dengan hotel di Yogyakarta untuk melaksanakan program One Hotel One Village. Saat ini ada 20 hotel yang membantu pemerintah dalam mendampingi dan mengembangkan desa wisata di DIY. Tujuan dari program ini adalah desa-desa wisata di Kulon Progo mendapatkan bimbingan dari pengelola hotel yang sudah mapan di Yogyakarta dalam hal pengelolaan homestay dan hospitality. Program lain adalah One Village One Sister Company yaitu kerjasama antara desa dengan perusahaan yang bertujuan untuk meningkatkan kesejahteraan masyarakat. Program One Village One Sister Company ini menggandeng 17 perusahaan swasta, BUMN dan BUMD untuk menjadi orangtua asuh dari desadesa di Kulon Progo. Perusahaan yang menjadi orangtua asuh diharapkan dapat membina desadesa yang menjadi asuhannya sehingga kesejahteraan di desa itu meningkat dan keluar dari angka kemiskinan.

Perguruan tinggi merupakan aktor lain yang juga dapat mendukung pengembangan CBT. Universitas dapat berperan sebagai fasilitator dan inisiator dalam pelaksanaan CBT. Kerjasama dengan perguruan tinggi dapat membantu dalam hal peningkatan pemahaman masyarakat lokal akan CBT dan inovasiinovasi dalam pengembangan CBT. Kemitraan dengan universitas akan mendidik masyarakat setempat tentang kerangka kerja yang tepatuntuk mengembangkan proyek-proyek berbasis masyarakat dan melengkapi organisasi dengan alat dan pendekatan guna meningkatkan kualitas pengalaman wisata. Perguruan tinggi juga akan berperan melalui kegiatan penelitian keahlian untuk menganalisis perubahan permintaan wisata dan penyediaan pelatihan/training guna peningkatan kapasitas pengelola program, yang 
berguna bagi pengembangan pariwisata berjenis CBT.

Selain pemerintah dan perguruan tinggi, pengelola CBT dapat bermitra dengan lembaga swadaya masyarakat dalam pengembangan CBT. LSM lokal dan internasional akan meningkatkan kapasitas masyarakat sebagai penanggung jawab atau pengelola CBT. Lembaga swadaya masyarakat dapat membantu pengembangan CBT melalui:

1. Bantuan dana atau pengembangan jaringan guna mendapatkan bantuan baik dari pemerintah atau pun lembaga donor nasional dan internasional.

2. Peningkatan kapasitas masyarakat (capacity building) masyarakat pengelola CBT melalui kegiatan pelatihan, workshop atau training tentang nature guiding, hospitality skills, business management dan kursus bahasa Inggris.

3. Jaringan pemasaran dan promosi wisata

Diskusi dan kegiatan ilmiah dalam merumuskan kebijakan pengembangan pariwisata dengan stakeholder lain misalnya perguruan tinggi, pemerintah dan masyarakat, Salah satu peran swasta di Daerah Istimewa Yogyakarta dalam pengembangan wisata di Kulon Progo adalah disepakatinya perjanjian kerja sama amtara pemerintah dan asosiasi hotel di Yogyakarta melalui program One Hotel One Village. Program One Hotel One Village ini bertujuan agar satu hotel di Yogyakarta dapat membantu membangun satu desa wisata di Kulon Progo. Fungsi hotel adalah mendampingi pihak desa wisata untuk meningkatkan kapasitas sumber daya manusia dan promosi. Di Daerah Istimewa Yogyakarta ada 20 hotel yang terlibat dalam program ini. Adapun desa wisata di Kulon Progo yang mendapatkan program One Hotel One Village adalah:

1. Desa wisata Jatimulyo, Girimulyo dengan Hotel Eastparc

2. Desa wisata Purwosari, Girimulyo dengan Hotel Grand Hyatt

3. Desa Wisata Sidorejo, Lendah dengan Hotel Cokro.

Masyarakat merupakan aktor kunci dalam pengembangan dan keberlanjutan CBT. Masyarakat merupakan aktor atau pelaku utama dalam pariwisata berbasis community driven ini. Masyarakat menjadi perencana, pelaksana dan pemnagwas implementasi CBT. Dalam merencanakan desa wisata dan program atau kegiatan unggulan, masyarakat yang dipimpin oleh kepala dusun dapat membentuk kelompok sadar wisata (Pokdarwis) dan pengelola desa wisata. Strategi pengembangan desa wisata melalui CBT dapat dilihat dalam Tabel 1. 


\section{Tabel 1. Strategi Pengembangan CBT}

\begin{tabular}{|c|c|c|}
\hline strategi & Apa yang harus dilakukan pengelola? & Apa yang diperoleh wisatawan? \\
\hline To See & $\begin{array}{l}\text { 1. Mengadakan berbagai event kesenian } \\
\text { dan budaya } \\
\text { 2. Memperbaiki infrastruktur fisik dan } \\
\text { ruang publik di daerah tujuan wisata } \\
\text { 3. Mengadakan fieldtrip di desa wisata }\end{array}$ & $\begin{array}{l}\text { 1. Pertunjukan kesenian tradisional, festival } \\
\text { budaya lokal, festival kuliner, pasar seni } \\
\text { dan pameran produk lokal } \\
\text { 2. Ruang pertunjukan wisata } \\
\text { 3. Paket wisata berbasis ecotourism, agro } \\
\text { tourism, dan socio-cultural tourism }\end{array}$ \\
\hline To Do & $\begin{array}{l}\text { 1. Melibatkan wisatawan dalam kegiatan } \\
\text { live in bersama warga } \\
\text { 2. Melibatkan wisatawan dalam melakukan } \\
\text { kegiatan konservasi lingkungan desa } \\
\text { wisata }\end{array}$ & $\begin{array}{l}\text { 1. Pengalaman pribadi secara psikologis, } \\
\text { emosional, dan sosial untuk berinteraksi } \\
\text { dengan masyarakat di desa wisata } \\
\text { 2. Mendapatkan edukasi dan praktik secara } \\
\text { langsung dalam melakukan konservasi } \\
\text { lingkungan desa wisata }\end{array}$ \\
\hline To Buy & $\begin{array}{l}\text { 1. Meningkatkan kekhasan potensi local } \\
\text { 2. Meningkatkan packing, branding, dan } \\
\text { marketing }\end{array}$ & $\begin{array}{l}\text { 1. Produk souvenir unggulan dari desa } \\
\text { wisata seperti susu bubuk kambing } \\
\text { etawa, teh, kopi, gula aren, kain batik } \\
\text { geblek renteng, dan makanan khas } \\
\text { lainnya. } \\
\text { 2. Kemudahan akses untuk membeli produk } \\
\text { souvenir dengan harga yang kompetitif. }\end{array}$ \\
\hline $\begin{array}{l}\text { To } \\
\text { Share }\end{array}$ & $\begin{array}{l}\text { 1. Mengadakan pameran, travel dialog dan } \\
\text { fieldtrip, deep ekstrem, majapahit travell } \\
\text { fair, gebyar wisata nusantara } \\
\text { 2. Publikasi melalui leaflet, media lokal } \\
\text { (KR, TVRI) dan nasional } \\
\text { 3. Melakukan benchmarking dengan daerah } \\
\text { tujuan wisata yang lain }\end{array}$ & $\begin{array}{l}\text { 1. Informasi potensi pariwisata dan paket } \\
\text { wisata secara lengkap dan berkualitas } \\
\text { 2. Update informasi dan dokumentasi }\end{array}$ \\
\hline $\begin{array}{l}\text { To } \\
\text { Empowe } \\
r\end{array}$ & $\begin{array}{l}\text { 1. Peningkatan kapasitas masyarakat desa } \\
\text { wisata } \\
\text { 2. Pengadaan sarana dan prasarana dalam } \\
\text { kegiatan pariwisata } \\
\text { 3. Peningkatan apresiasi seni dan budaya } \\
\text { 4. Inisisasi membangun jaringan kemitraan } \\
\text { ekonomi dengan dunia usaha } \\
\text { 5. Memotivasi masyarakat untuk lebih } \\
\text { mengembangkan produk lokal dengan } \\
\text { brand local }\end{array}$ & $\begin{array}{l}\text { 1. Pelayanan pariwisata yang berkualitas } \\
\text { 2. Berpartisipasi dalam pemberdayaan } \\
\text { ekonomi dan sosial masyarakat di desa } \\
\text { wisata }\end{array}$ \\
\hline $\begin{array}{l}\text { To } \\
\text { Sustain }\end{array}$ & $\begin{array}{l}\text { 1. Penguatan kapasitas SDM dan } \\
\text { kelembagaan kelompok sadar wisata } \\
\text { 2. Pendampingan pengembangan program- } \\
\text { program desa wisata, promosi wisata, } \\
\text { dan membangun jejaring dengan pihak } \\
\text { ketiga seperti hotel, LSM, seniman, } \\
\text { perguruan tinggi, pusat studi, dan } \\
\text { konsultan }\end{array}$ & $\begin{array}{l}\text { 1. Keramahtamahan masyarakat desa wisata } \\
\text { 2. Pengelolaan desa wisata yang profesional } \\
\text { 3. Program pendampingan sosial yang } \\
\text { dikemas dalam bentuk community based } \\
\text { tourism }\end{array}$ \\
\hline
\end{tabular}

Sumber: Penelitian (2016) 
Peran peminpin dalam masyarakat sangat penting untuk menggerakkan masyarakat guna berperan aktif dalam kegiatan CBT. Ketua Pokdarwis dan ketua pengelola desa wisata dapat memimpin dan mengorganisir masyarakat baik dalam tahap perencanaan, pelaksanaan dan pengawasan CBT. Masyarakat sebagai pemilik dan pengelola dapat menjadi bagian dari atraksi wisata untuk menarik wisatawan dengan cara mengenalkan kebudayaan dan kebiasaan sehari-hari yang menjadi keunikan dan ciri khas dari objek wisata. Terdapat beberapa hambatan dalam pengembangan CBT dijelaskan sebagai berikut:

1. Belum semua warga masyarakat memiliki pandangan yang positif terhadap pengembangan CBT. Kondisi ini mengakibatkan pengembangan CBT belum secara maksimal dinikmati oleh masyarakat. Pada daerah di mana seluruh masyarakat memiliki kesamaan pemahaman dan semangat untuk memajukan sector pariwisata, pemberdayaan ekonomi berlangsung dengan baik, misalnya di desa wisata Nglinggo dan Jatimulyo.

2. Keterbatasan dana masyarakat untuk dapat menyediakan penginapan yang standar bagi wisatawan. Kurangnya modal dan keterbatasan dana yang dimiliki masyarakat menyebabkan sarana homestay yang disediakan warga masyarakat kurang layak atau standar bagi wisatawan, misalnya sarana kamar mandi dan toilet yang kurang bersih dan kurang layak bagi wisatawan.

3. Ketidakmampuan warga masyarakat untuk menyiapkan oleh-oleh dan souvenir yang menarik bagi wisatawan. Kabupaten Kulon Progo memiliki sejumlah potensi yang khas dan unggulan, namun masyarakat belum mampu mengemas potensi tersebut menjadi produk oleh-oleh atau souvenir yang menarik bagi wisatawan.

4. Masih minimnya dukungan dari pihak swasta dalam implementasi CBT. Meskipun sejumlah program seperti one hotel one village sudah diterapkan di Kulon Progo sebagai bentuk peran swasta dalam mengembangkan wisata, namun hasilnya belum signifikan dalam membantu pengembangan CBT di Kulon Progo.

5. Sarana infrastruktur belum memadai, misalnya sarana jalan dan sarana pendukung lain misalnya keamanan dan kenyamanan objek wisata. Jalan menuju objek wisata seperti 
Nglinggo, Jatimulyo dan desa wisata lain yang berada di puncak perbukitan semestinya perlu diperlebar sehingga memudahkan bagi bus dan kendaran besar lain untuk mengakses. Pihak tour travel kadang harus berpikir dua kali jika akan membawa wisatawan menuju objek wisata yang sulit diakses oleh bus.

\section{SIMPULAN}

Dalam pengembangan CBT, seluruh stekeholders terlibat dalam perencanaan, implementasi dan pengawasan. Adapun tahapan yang perlu ditempuh untuk penerapan CBT adalah:

1. Identifikasi potensi wisata

2. Menyiapkan Masyarakat untuk Berperan dalam CBT. Semua warga masyarakat mulai dari anak-anak, remaja, dewasa, bahkan lansia (masyarakat lanjut usia) dilibatkan dan dipahamkan agar pola pikir (mindset) dalam memandang tamu atau wisatawan yang datang tadinya dianggap sebagai saingan diubah menjadi aset dan sumber kehidupan. Pemberdayaan masyarakat dapat dilakukan melalui pendidikan yang meliputi keterampilan, sikap/tata krama, aturan bermasyarakat, adat, bahkan sampai pada penampilan masyarakat itu sendiri.
3. Menentukan pemimpin dalam CBT. Pemimpin di bidang pariwisata adalah sosok yang dapat membuat akselerasi cepat dan inovasi terbaik untuk membuat pariwisata lebih baik lagi ke depan. Karakteristik yang diperlukan untuk menjadi pemimpin lokal pariwisata, antara lain: sabar, berani, dinamis, visioner, proaktif, inovatif, komunikator yang baik, peka, berdisiplin, dan kreatif.

2. Mengembangkan Organisasi Masyarakat Setempat. Pengembangan organisasi kemasyarakatan setempat ini (seperti: Kelompok Sadar Wisata, PKK, KWT, kelompok karang taruna) dapat dilakukan dengan upaya penguatan kapasitas kelembagaan dan sumberdaya manusianya secara berkelanjutan.

3. Selain kelompok yang secara langsung terkait dengan kegiatan pariwisata seperti pokdarwis, desa wisata, yang juga tidak kalah pentingnya adalah peran organisasi wanita (seperti: PKK dan KWT) dan organisasi pemuda yang ada di wilayah pengembangan pariwisata tersebut.

4. Dalam pengembangan dan keberlanjutan CBT, integrasi peran dan dukungan dari seluruh komponen yaitu pemerintah, swasta, lembaga swadaya masyarakat (NGO), 
perguruan tinggi, dan masyarakat sangat diperlukan khususnya dalam bentuk promosi wisata, pengelolaan desa wisata, dan pendampingan pemberdayaan masyarakat.

Pemberdayaan Ekonomi Masyarakat melalui $C B T$ di Kabupaten Kulon Progo dilakukan dengan strategi: 1)to see,2) to do, 3)to buy, 4)to share, 5)to empower dan 6) to sustain.

\section{DAFTAR PUSTAKA}

CIFOR. 2004. Pembangunan Pariwisata Berbasis Masyarakat. CIFOR, Bogor.

Davey, Kenneth J. 1998. "Pembiayaan Pemerintahan Daerah, PraktekPraktek Internasional dan Relevansinya Bagi Dunia Kerja", Jakarta: UI Press.

Ditjen Pengembangan Destinasi Pariwisata, Departemen Kebudayaan dan Pariwisata dan WWF Indonesia. 2009. Prinsip dan Kriteria Ekowisata Berbasis Masyarakat. Jakarta: Departemen Kebudayaan dan Pariwisata dan WWF Indonesia.

Durbarry, Ramesh. 2004. Tourism Economic Growth: the case of Caurities. Tourims Eonomics, (10 4, 389-401. IP Publishing Ltd.

Moleong, Lexy J. 2010. "Metodologi Penelitian Kualitatif”. Bandung: Remaja Rosdakarya.
Nawawi, Ismail. 2009. Public Policy: Analisis, Strategi Advokasi Teori, dan Praktek. Surabaya: Putra Media Nusantara.

Pendit, Nyoman S. 2003. "Ilmu Pariwisata 'Sebuah Pengantar Perdana”, Jakarta: Pradnya Paramita.

Sinclair, Thea. 1998. Tourism and Economic Development:a survey. Journal of Development Studies, 5, $1-51$.

Spillane, James J. 1987. "Ekonomi Pariwisata Sejarah dan Prospeknya”, Yogyakarta: Kanisius.

Suansri, P. 2003. Comunity Based TourismHandbook. Bangkok, Thailand: Responsible Ecological Social Tours (REST) Project.

Sunaryo, Bambang. 2013. Kebijakan Pembangunan Destinasi Pariwisata Konsep dan Aplikasinya di Indonesia. Yogyakarta: Gava Media.

Suwantoro, Gamal. 2004. "Dasar-Dasar Pariwisata”, Yogyakarta: Andi

Winarno, Budi, 2008, Kebijakan Publik,Yogyakarta, Gama press

Yoeti, Oka. A. 2001. "Manajemen Pariwisata”, Jakarta: Pradnya Paramita

Statistik Kepariwisataan Provinsi Daerah Istimewa Yogyakarta tahun 2011

Instruksi Presiden Inpres No. 9 Tahun 1969 tentang Pengelolaan Pariwisata 30 
Peraturan Daerah Kabupaten Kulon Progo No. 1 Tahun 2012 tentang Rencana Tata Ruang Kabupaten Kulon Progo

Undang - Undang No. 32 tahun 2004 tentang Otonomi Daerah.

http://indonesiaantravels.com/pariwisataberbasis-masyarakat/, diakses tanggal 12 September 2015, pukul 13.00 . 